\title{
PRELIMINARY STUDY OF THE URANIUM POTENTIAL OF THE TRIASSIC SANFORD BASIN AND COLON CROSS STRUCTURE, NORTH CAROLINA
}

BENDIX FIELD ENGINEERING CORPORATION

Grand Junction Operations

Grand Junction, Colorado 81501

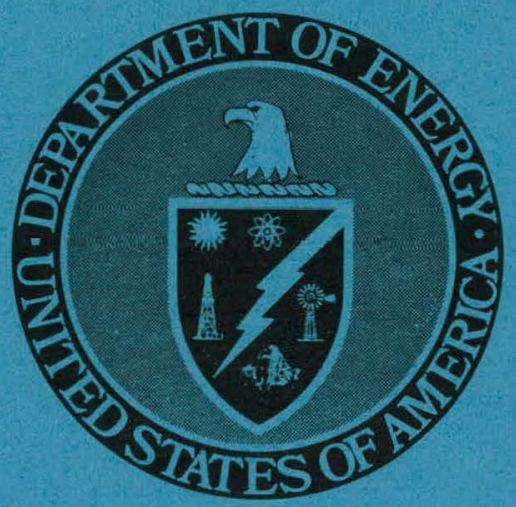

ISSUED BY THE U.S. DEPARTMENT OF ENERGY GRAND JUNCTION OFFICE UNDER CONTRACT NO. E(05-1)-1664 


\section{DISCLAIMER}

This report was prepared as an account of work sponsored by an agency of the United States Government. Neither the United States Government nor any agency Thereof, nor any of their employees, makes any warranty, express or implied, or assumes any legal liability or responsibility for the accuracy, completeness, or usefulness of any information, apparatus, product, or process disclosed, or represents that its use would not infringe privately owned rights. Reference herein to any specific commercial product, process, or service by trade name, trademark, manufacturer, or otherwise does not necessarily constitute or imply its endorsement, recommendation, or favoring by the United States Government or any agency thereof. The views and opinions of authors expressed herein do not necessarily state or reflect those of the United States Government or any agency thereof. 


\section{DISCLAIMER}

Portions of this document may be illegible in electronic image products. Images are produced from the best available original document. 
This report was prepared as an account of work sponsored by the United States Government. Neither the United States nor the United States Department of Energy, nor any of their employees, nor any of their contractors, subcontractors, or their employees, makes any warranty, expressed or implied, or assumes any legal liability or responsibility for the accuracy, completeness or usefulness of any information, apparatus, product or process disclosed, or represents that its use would not infringe privately owned rights. 
PRELIMINARY STUDY OF THE URANIUM POTENTIAL OF THE TRIASSIC SANFORD BASIN AND COLON CROSS STRUCTURE, NORTH CAROLINA

C. H. Lee

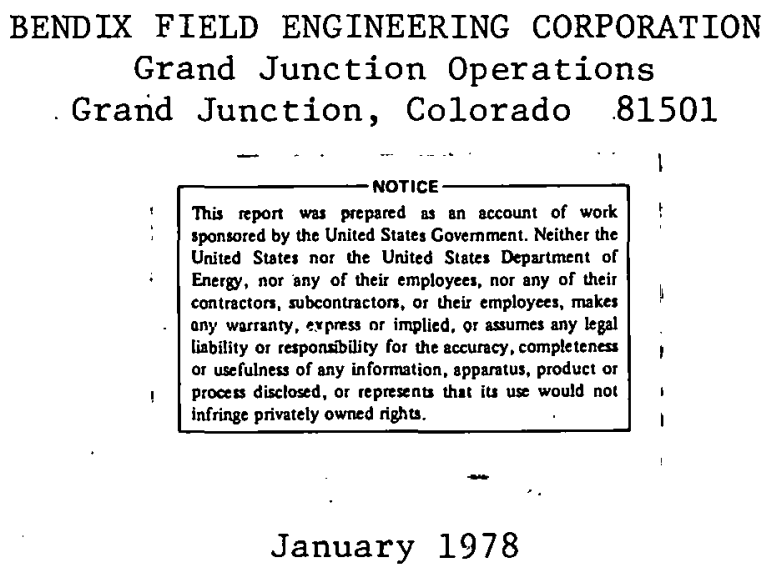

PREPARED FOR THE U.S. ENERGY RESEARCH AND DEVELOPMENT ADMINISTRATION UNDER CONTRACT NO. EY-76-C-13-1664

ISSUED BY THE U.S. DEPARTMENT OF ENERGY, GRAND JUNCTION OFFICE 


\section{THIS PAGE}

\section{WAS INTENTIONALLY \\ LEFT BLANK}


CONTENTS

Page

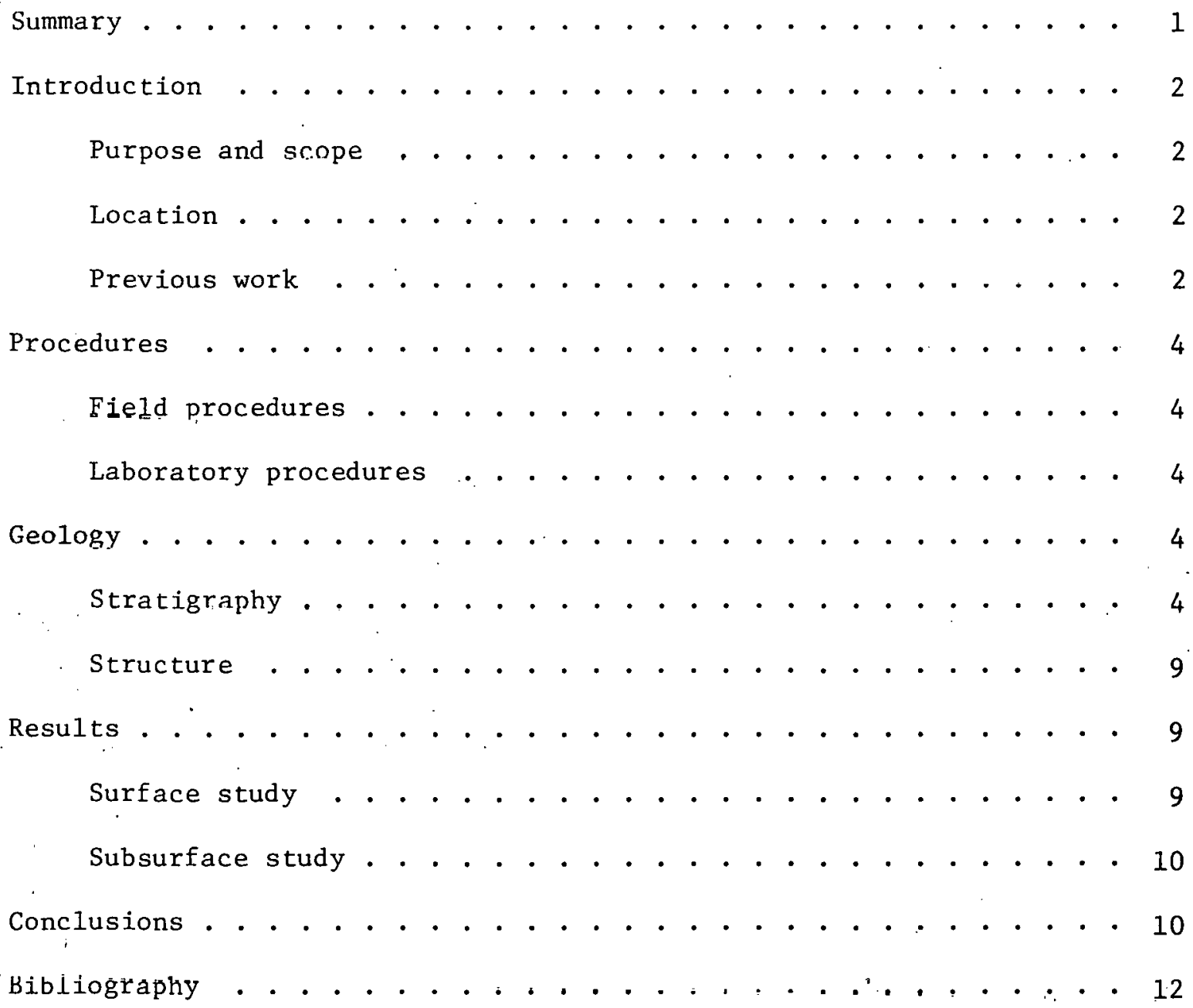




\section{ILLUSTRATIONS}

$\underline{\text { Page }}$

Figure 1. Sample location map of the Triassic Sanford basin and Colon cross structure, North Carolina . . . . 3

2. Geologic and structural map of the Triassic Sanford basin and Colon cross structure, North Carolina . . . . . . . . . . . . 7

3. Generalized stratigraphic section and description of rock units in the Triassic Sanford Basin . . . . . . . . . . . . . 8

Plate 1. Geologic cross sections of the Triassic In Sanford basin, North Carolina ............ Pocket

\section{TABLES}

Table 1. Laboratory analyses of rock and soil samples from the Triassic Sanford basin, Colon cross structure, and adjacent slate belt... . . . . . . . 5 
SUMMARY

A preliminary geologic investigation was conducted to determine if the Triassic sedimentary rocks of the Sanford basin and Colon cross structure in North Carolina are favorable hosts for uranium deposits. Rocks of the adjacent Carolina slate belt were also examined as a potential source of uranium.

On the basis of favorability criteria for sandstone-type uranium deposits, and geologic and geophysical investigations of the study area, the most favorable sites for further investigation are (1) at the contacts between the Pekin and Cumnock and between the Pekin and Sanford Formations near the Colon cross structure and (2) at the base of the Jonesboro fault, which lies below the Sanford Formation, northwest of Sanford.

The highly weathered granites southeast of the Jonesboro fault were a source of the detritus deposited on the cross structure and may have been a primary snurre of uranium. Uranium leached from the coarse sediment (Pekin Formation) of the cross structure may have been transported downdip and llidy have been precipitated by the carbonaceous shales of the Cumnock Formation on the western side of the cross structure or at the Pekin-Sanford contact to the east.

The Jonesboro fault may provide an impermeable barrier to ground-water migration in the metamorphosed basement rocks below the Triassic sediments. Such a barrier would constitute a favorable site for the precipitation and retention of uranium.

Scintillometer surveys and laboratory analyses indicate no anomalous surface radioactivity in the study area. However, deep surface weathering may have caused the uranium to be leached from the exposed rocks and redeposited at depth.

Subsurface information was limited to rock cores from two test holes in the Sanford and Cumnock Formations in the northwestern part of the basin and to geophysical logs from a test hole to basement in the central part. A scintillometer scan of the core indicated no anomalous radioactivity, but examination of the gamma-ray logs revealed a slight increase in radioactivity in pyritic siltstones near basement in the Pekin Formation.

Geologic investigations show that conditions which have proven favorable for deposition of uranium in other areas are present in the Triassic rocks of the Sanford basin and Colon cross structure. However, because of deep surface weathering, further subsurface studies are necessary to confirm the favorability of the rocks as hosts for urantum. 
INTRODUCTION

PURPOSE AND SCOPE

Many of the characteristics considered favorable for fluvial sandstonetype uranium deposits have been observed in rocks within the Triassic basins of North Carolina (Dennison and Wheeler, 1972, p. 9-14, 171-176). This preliminary study was designed to determine whether the sandstone formations in the 500-sq-mi Sanford basin and Colon cross structure in North Carolina are favorable as host rocks for uranium deposition, and to examine the possible source of uranium. The study was conducted by Bendix Field Engineering Corporation for the Grand Junction Office of the U.S. Energy Research and Development Administration, which became part of the Department of Energy on October 1, 1977.

The study involved 3 weeks of field work during October and November 1976. Several traverses were conducted across the basin, the cross structure, and the areas adjacent to the Triassic rocks to measure surface radioactivity and to collect samples. Radiometric measurements were obtained at 150 locations, and 42 samples were collected for laboratory analyses. Rock cores from coal test holes and geophysical logs from an oil test hole were examined for anomalous radioactivity. The sample locations and drill-hole locations are shown in Figure 1 .

\section{LOCATION}

The Sanford basin and Colon cross structure constitute the southern half of the Deep River basin in central North Carolina. The study area is approximately $35 \mathrm{mi}$ long by $15 \mathrm{mi}$ wide and occupies parts of Lee, Moore, and rhatham Countics.

\section{PREVIOUS WORK}

Geolog1c investigations of the Triassic Deep River basin were conducted by Olmsted (1820), Emmons (1856), Campbell and Kimball (1923), Reinemund (1955), Mann and Zablocki (1961), Conley (1962), and Ackermann and others (1976).

Rock cores from coal tests conducted in Chatham County for the U.S. Bureau of Mines (Reinemund, 1955, p. 131-138) were made available by the North Carolina State Division of Mineral Resources. The same agency also provided geophysical logs from an oil test drilled in Lee County for the Chevron Oil Company during September and October 1964.

Stream-sediment and ground-water samples from the Sanford basin area have been analyzed for uranium by the Savannah River Laboratory. Stream-sediment samples collected from Moore County ranged from 0 to $500 \mathrm{ppm}$ uranium (Savannah River Lab., 1976, p. 29). Precise sample locations were not available.

An airborne radiometric study of the Triassic basins in North Carolina was conducted in 1975 by Geodata International Incorporated under contract to the U.S. Energy Research and Development Adm1nistration. 


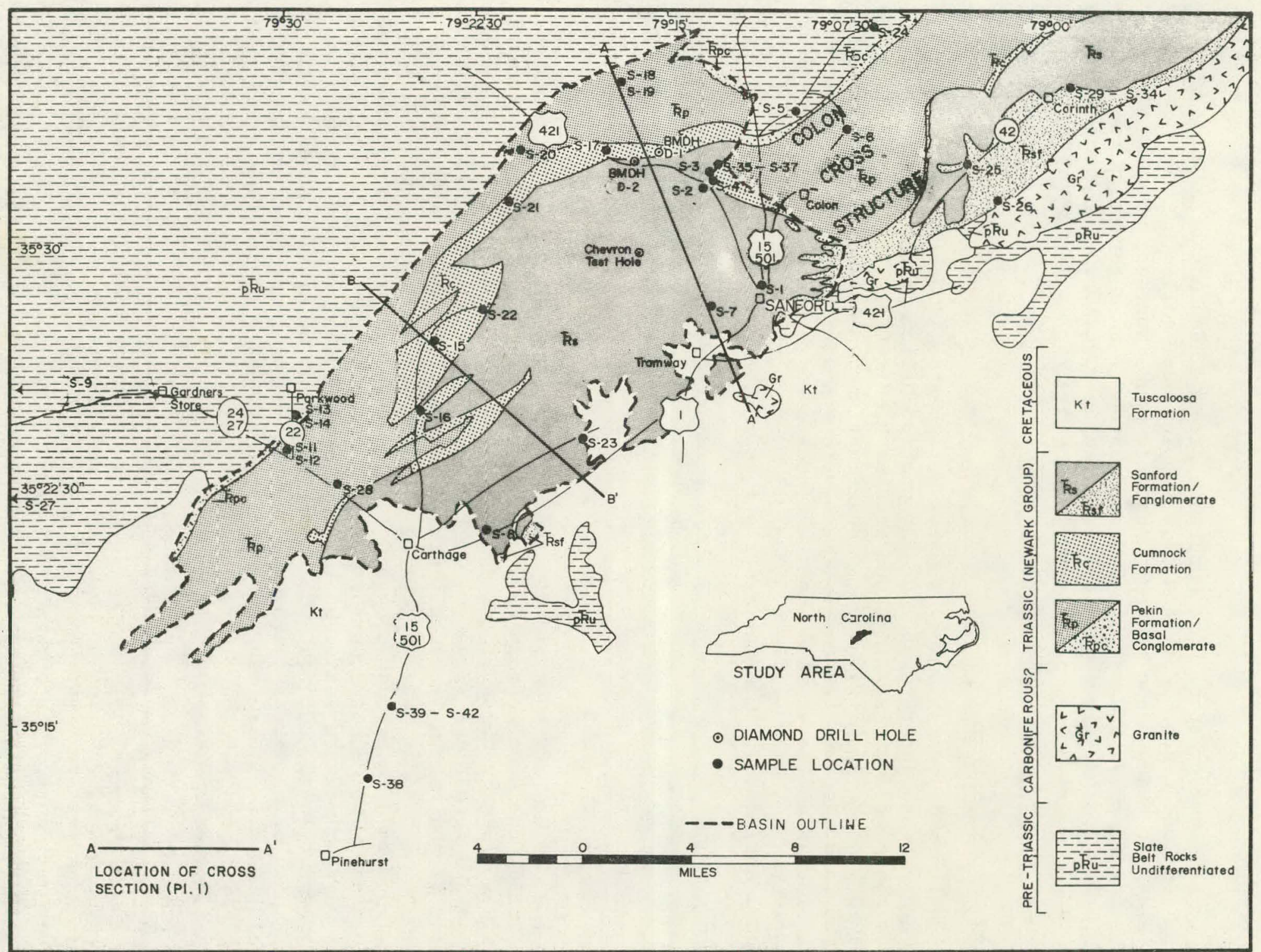

Figure 1. Sample location map of the Triassic Sanford basin and Colon cross structure, North Carolina (after Reinemund, 1955). 


\section{PROCEDURES}

\section{FIELD PROCEDURES}

Scintillometer scans were conducted across the study area and on rock cores from coal tests. Rock and soil samples were collected from outcrops in fields, at highway and railroad cuts, in rock quarries, in clay and gravel pits, and at excavation sites. Several contacts, unconformities, and fault zones, reported by Reinemund (1955) and Conley (1962), were investigated and sampled.

\section{LABORATORY PROCEDURES}

Analyses of rock and soil samples were performed at the analytical and petrographic laboratory of the Grand Junction Office of the Energy Research and Development Administration operated by Bendix Field Engineering Corporation. Gamma-ray spectroscopy was used to determine equivalent amounts of potassium, uranium, and thorium; fluorometric analysis was used to determine amounts of chemical uranium (Table 1). The techniques used in these studies were described by Latimer and others (1970, p. 138-141). Petrographic examinations consisted of modal analyses and mineral descriptions of thin sections.

\section{GEOLOGY}

\section{STRATIGRAPHY}

The sedimentary rocks in the Sanford basin and Colon cross structure are part of the Newark Croup (Reinemund, 1955, p. 26). The Lhree sedimentary units described by Campbell and Kimball (1923, p. 20) are the Pekin, Cumnock, and Sanford Formations (Figs. 2, 3; P1. 1). The Pekin and Sanford Formations consist of red, brown, or purple arkosic and argillaceous rocks that grade from conglomerate or fanglomerate to claystone. Subordinate amounts of gray to brown arkosic sandstone and conglomerate are exposed throughout the study area. The Cumnock consists of gray and black arkosic and argillaceous rocks that grade from sandstone to claystone and shale. Two coal seams are also present in the Cumnock. The three units may be distinguished by differences in color and gross lithology, but the contacts are often gradational and difficult to locate (Reinemund, 1955, p. 39-53). Petrographic analyses of rock samples indicate mineral compositions and rock types consistent with those reported by Reinemund (1955, p. 39-52).

The basal conglomerate and sandstone of the Pekin Formation were derived from the pre-Triassic slate belt rocks, west of the Deep River basin. However, most of the sediments in the basin and cross structure were eroded from the highland southeast of the basin and were carried westward by streams. The coarser sediments of the Pekin and Sanford Formations were primarily deposited in channels and alluvial fans. The finer sediments were deposited on flood plains (Reinemund, 1955, p. 52-53). Reinemund (1955, p. 53) suggested that these sediments were derived from red soils of weathered pre-Triassic metamorphic 
TABLE 1. LABORATORY ANALYSES OF ROCK AND SOIL SAMPLES FROM THE TRIASSIC

SANFORD BASIN, COLON CROSS STRUCTURE, AND ADJACミNT SLATE BELT

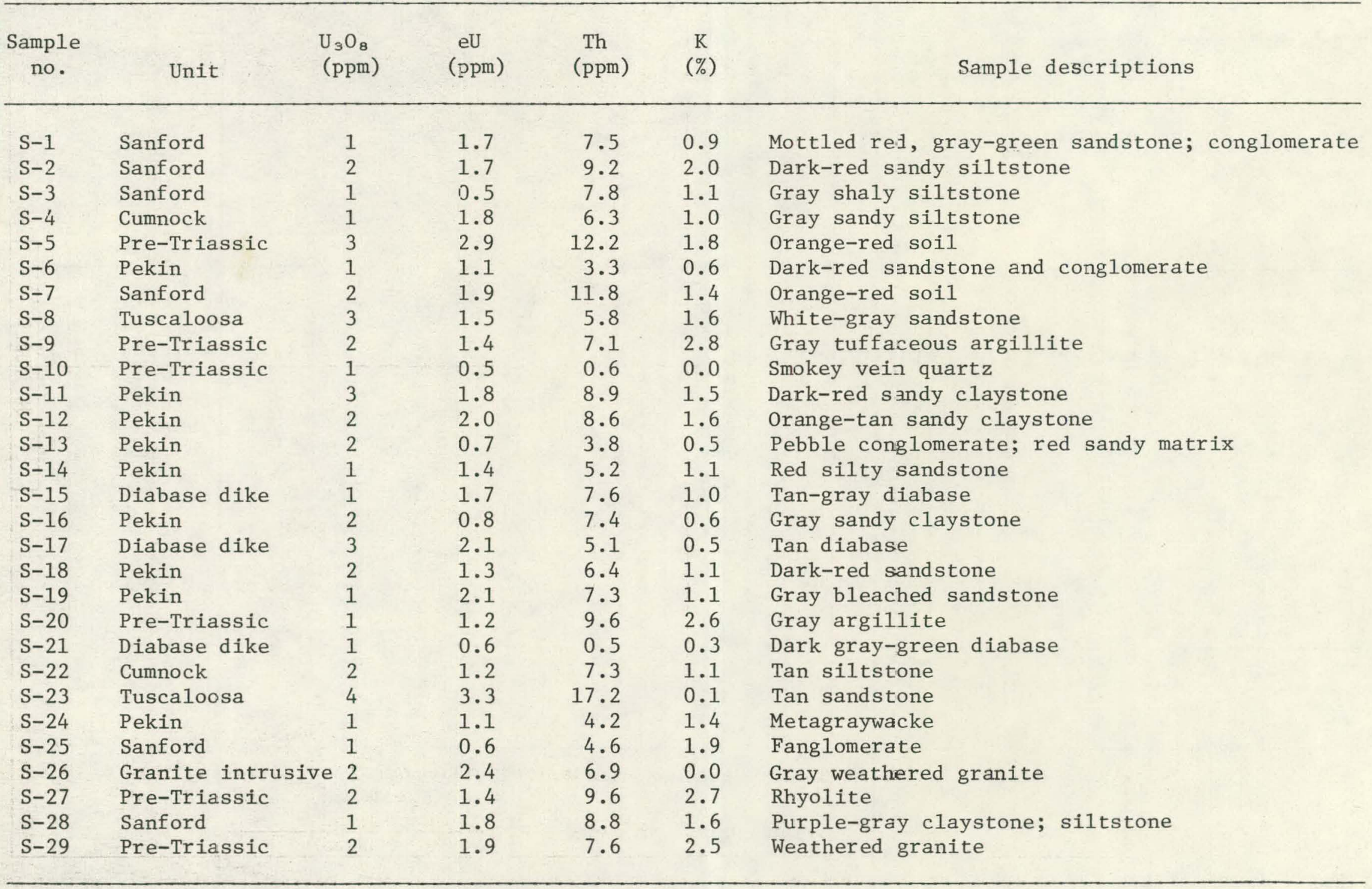


TABLE 1. (continued)

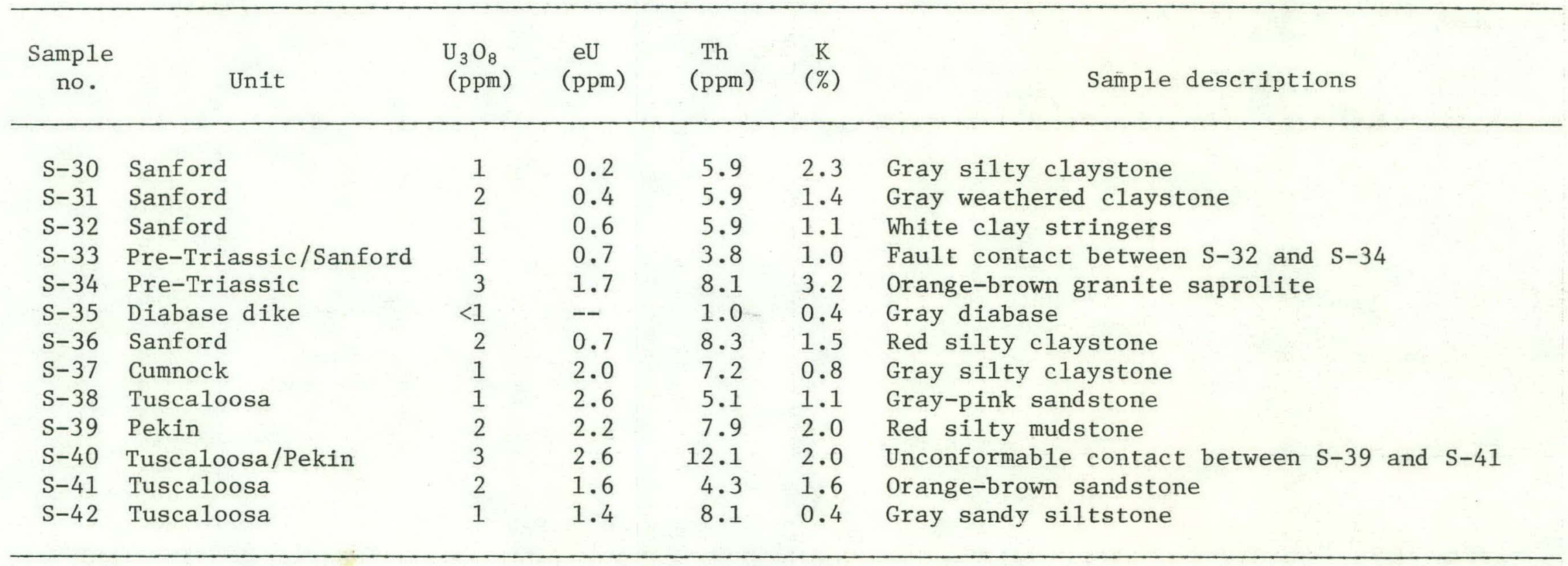




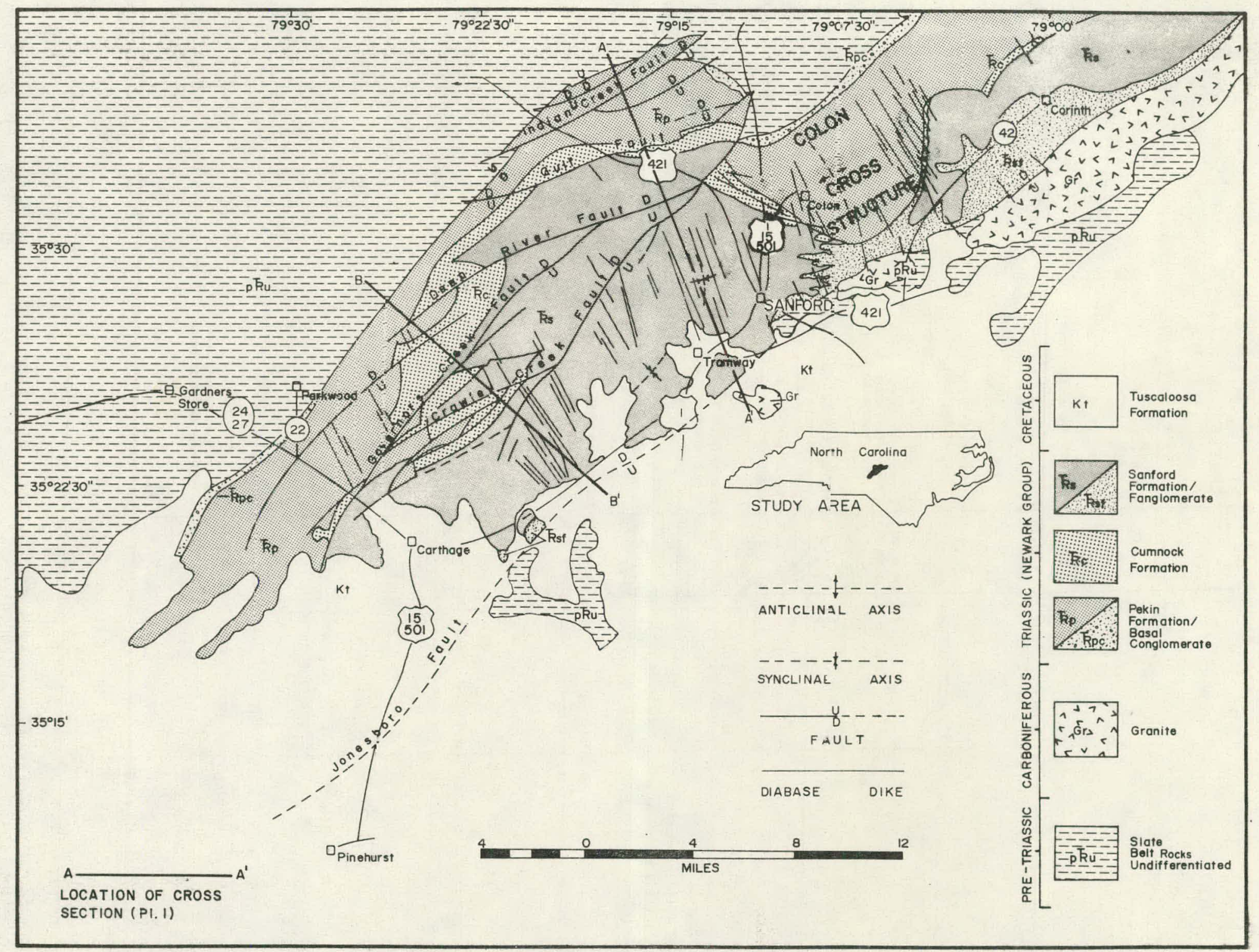

Figure 2. Geologic and structural map of the Triassic Sanford basin and Colon cross structure, North Carolina (after Reinemund, 1955). 


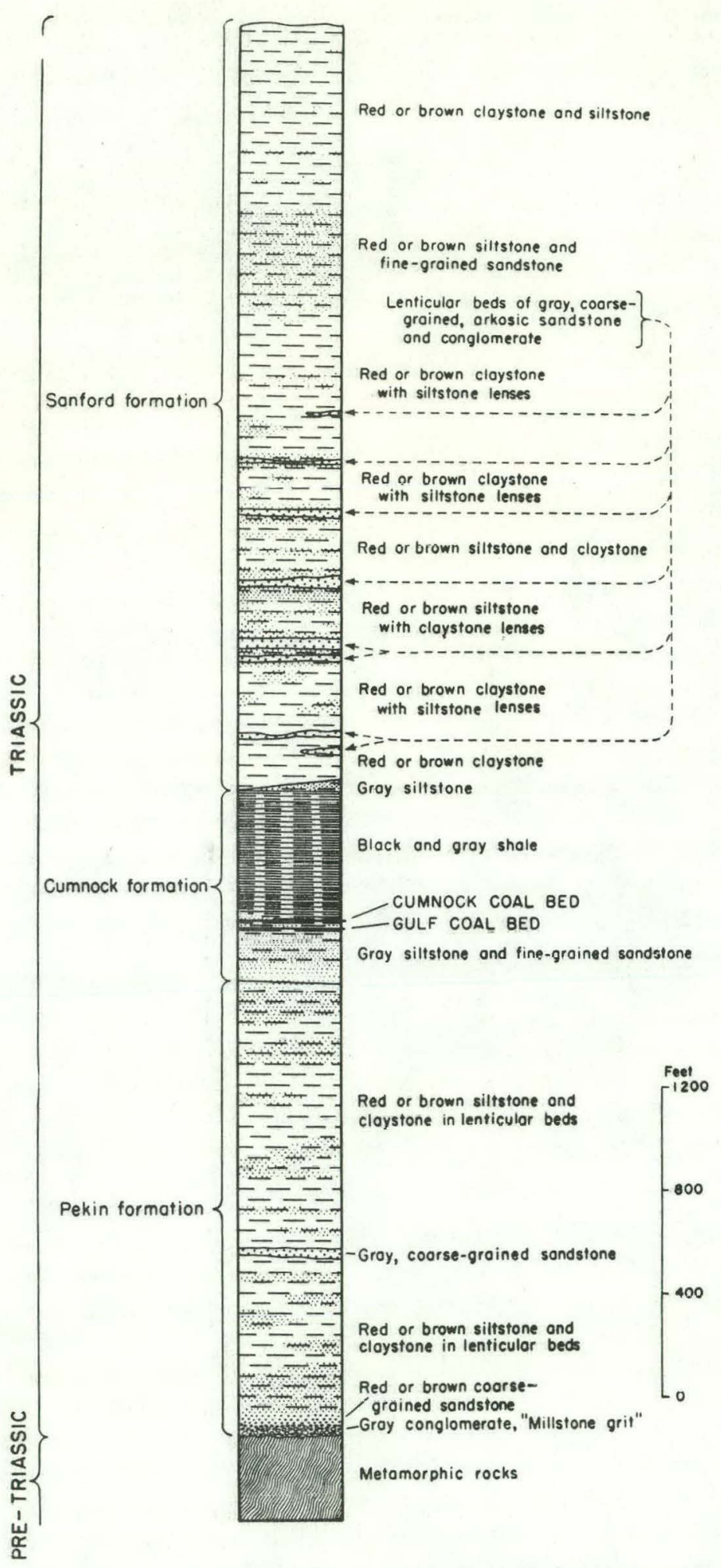

Figure 3. Generalized stratigraphic section and description of rock units in the Triassic Sanford Basin (from Reinemund, 1955). 
rocks that were transported into the basin by streams. The red coloration of the Pekin and Sanford rocks indicates deposition in an oxidizing environment. In contrast, the gray rocks of the Cumnock were deposited in a swampy or lacustrine reducing environment.

Reinemund (1955, p. 27) stated that the thickness of Triassic rocks. is 7,000 to $8,000 \mathrm{ft}$ in the Sanford basin and 4,000 to 5,000 ft in the Colon cross structure. Ackermann and others (1976, p. 139), who estimated thick-. nesses in the basin and cross structure from resistivity data, agreed. In general with Reinemund. On the basis of gravity studies, however, Mann and Zablocki (1961, p. 212-213) suggested a maximum of $6,100 \mathrm{ft}$ of sediment in the Sanford basin and 2,000 $\mathrm{ft}$ in the area of the Colon cross structure.

The diabase dikes are generally dark gray to olive black and contain plagioclase, pyroxene, olivine, and opaque minerals. The grain size ranges from $3.5 \mathrm{~mm}$ to less than $0.5 \mathrm{~mm}$ (Reinemund, 1955, p. 59). Dikes, which are as much as $300 \mathrm{ft}$ wide and $7 \mathrm{mi}$ long, have intruded northwest-trending joints and cross faults. Because they displace the longitudinal faults, intrude the youngest Triassic rocks, and do not intrude the Cretaceous or younger rocks, Reinemund (1955, p. 61) believed that the dikes probably were formed during the final stages of faulting near the end of the Triassic Period.

\section{STRUCTURE}

The Sanford basin is a half-graben that contains sedimentary rocks and occupies a northeast-trending depression in the Slate Belt rocks of the Piedmont. province (Figs. 1, 2; P1. 1). The basin probably originated as a down-faulted block, and the present structure evolved through differential subsidence accompanied by drag-folding and upward tilting of the beds along the Jonesboro fault (Reinemund, 1955, p. 75-76). The rocks in the basin generally dip southeastward at an average angle of approximately $15^{\circ}$. The southeastern boundary of the basin is the Jonesboro fault, which is more than $100 \mathrm{mi}$ long and has a vertical displacement of approximately 6,000 to 10,000 ft. A series of longitudinal faults nearly parallel to the Jonesboro fault are cut and offset hy a series of transverse faults and diabase dikes.

The Colon cross structure is a northwest-trending anticlinal cross fold that interrupts the northeast-trending synclinal form and separtes the Durham and the Sanford basins. The cross fold affects both the Triassic strata and the pre-Triassic basement rocks. Reinemund (1955, p. 75) suggested that the cross fold was formed by sedimentation and the simultaneous movement of the Jonesboro fault. Later, the cross fold was cut by a series of transverse faults and dikes to form the present structure.

\section{RESULTS}

\section{SURFACE STUDY}

Radiometric surveys in the Sanford basin, the Colon cross structure, and the adjacent Slate Belt rocks revealed no anomalous radioactivity. Laboratory analyses of rock and soil samples did not disclose anomalous uranium 
mineralization. However, Overstreet (1970, p. 381) noted that deep surface weathering in the southeastern states precludes significant ore deposits at the surface. Uranium possibly has been leached. from exposed rocks and redeposited downdip.

\section{SUBSURFACE STUDY}

Several coal test holes were drilled in Lee and Chatham Counties through the Sanford and Cumnock Formations near the northwestern border of the Sanford basin (Reinemund, 1955, p. 127-156). A scintillometer scan of the cores from two of these holes revealed no anomalous radioactivity.

Geophysical logs of an oil test drilled in Lee County for the Chevron 0il Company showed an increased level of radioactivity in a gray to black, pyritic siltstone in the Pekin Formation, approximately $35 \mathrm{ft}$ thick, near the metamorphosed basement rocks. However, the core from this hole was not available for analysis.

\section{CONCLUSIONS}

On the basis of criteria for sandstone-type uranium deposits (Grutt, 1972) the Sanford basin and Colon cross structure contain rocks which are favorable as hosts for uranium deposition. 0xidized, arkosic, fluvial-deltaic sandstones, claystones, and shales, which intertongue with reduced sandstones and claystones, are predominant in the Pekin and Sanford Formations. The Cumnock Formation contains carbonaceous shales that formed in a lacustrine environment and that may have caused reduction and precipitation of uranium. Faults and diabase dikes, which can form impermeable barriers to mineralized solutions, occur throughout the basin and aling its bordarg.

According to Reinemund (1955, p. 53), the anticlinal Colon cross structure was the primary locus of drainage for the Sanford basin throughout most of Triassic time. Coarse sediments were deposited on the cross structure and finer sediments were deposited in the basins. Pre-Triassic granitic bodics, east of the cross structure and adjacent to the Jonesboro fault, were a source of detrital material and were the most likely source of uranium for the basin (Fig. 2).

West of the cross structure, the black shales of the Cumnock, which are in contact with and downdip from the coarse sandstones of the Pekin (Fig. 2), create a favorable situation for uranium reduction and deposition. Downdip from and northeast of the cross structure, the diabase dikes and faults may have provided effective traps for emplacement of uranium deposits. According to Reinemund (1955, p. 40), an angular unconformity separates the Pekin from the overlying Sanford Formation along the eastern and southeastern limbs of the cross structure. Grutt (1972, p. 50) suggested that unconformities may play a significant role in uranium deposition. From gravity surveys in the study area, Mann and Zablocki (1961, p. 206-208) reported that 2,000 ft is the maximum thickness of the Triassic sediments parallel to the contact between the Pekin and Sanford Formations northeast of the Colon cross structure. The sediments on the southwestern side are approximately the same thickness. 
The Jonesboro fault, which bounds the deepest part of the basin, may provide an impermeable trap for uranium moving near the metamorphosed basement rocks. Mann and Zablocki (1961, p. 208) state that the Sanford basin attains a maximum depth of approximately 5,800 ft northwest of Sanford. This area is downdip from both the western border and the colon cross structure. The Chevron oil test showed abundant pyrite, which is a good reductant for uranium, in the Pekin Formation approximately $4 \mathrm{mi}$ northwest of Sanford (Fig. 1): 
Ackermann, H. D., Bain, G. L., and Zohdy, A.A.R., 1976, Deep exploration of an east coast Triassic basin using electrical resistivity: Geology, v. 4, no. 3, p. 138-139.

Bryson, H. J., 1937, The mining industry in North Carolina from 1929 to 1936: North Carolina Dept. Conserv, and Devel. Econ. Paper 64, 714 p.

Campbe11, M. R., and Kimbal1, K. W., 1923, The Deep River coal field of North Carolina: North Carolina Geol. and Econ. Survey Bull. 33, 95 p.

Conley, J. F., 1962, Geology and mineral resources of Moore County, North Carolina: North Carolina Dept. Conserv, and Devel. Bull. 76, 40 p.

Dennison, J. M., and Wheeler, W. H., 1972, Precambrian through Cretaceous strata of probable fluvial origin in southeastern United States and their potential as uranium host rocks: U.S. Atomic Energy Comm. GJO-4168-1, Open-File Rept., p. 9-14.

Emmons, Ebenezer, 1856, Geological report of the midland counties of North Carolina: New York, George P. Putnam and Co., 347 p.

Geodata International, Inc., 1975, Aerial radiometric and magnetic survey of central Appalachian Triassic basin - parts of Virginia and the Carolinas: U.S. Energy Research and Devel. Adm. GJO-1664, Open-File Rept., v. 1, 53 p.

Grutt, E. W., Jr., 1972, Prospecting criteria for sandstonc-type uranium deposits, in Bowie, S.H.U., Davis, Michael, and Ostle, Dennis, eds., Uranium prospecting handbook: London, England, Inst, Mining Metal1., P. 1777.

Latimer, J. N., Bush, W. E., Higgins, L. J., and Shay, R. S., eds., 1970, Handbook of analytical procedures: U.S. Atomic Energy Comm. RMO-3008 Open-File Rept., 300 p.

Mann, V. I., and Zablocki, F. S., 1961, Gravity fcatures of the Deep River Wadesboro Triassic basin of North Carolina: Southeastern Geology, v. 2, no. 4, p. 191-215.

McIntosh, F. K., 1944, Project 815, Deep River coal field, Chatham County, North Carolina: U.S. Rur. Mines War Minerals Rept. (unpub. rept.).

O1msted, Dennison, 1820, Red sandstone formation of North Carolina: Am. Jour. Sci., 1st ser., v. 2, p. 175-176.

Overstreet, W. C., 1970, The Piedmont in South Carolina, Chap. 25, in Fisher, G. W., Pettijohn, F. J., Reed, J. C., Jr., and Weaver, K. N., eds., Studies of Appalachian geology, central and southern: New York, Wiley and Son, p. 381. 
Prouty, W. F., 1931, Triassic deposits of the Durham Basin and their relation to other Triassic areas of eastern United States: Am. Jour. Sci., 5th ser., v. 21 , no. 126 , p. 473-490.

Reinemund, J. A., 1955, Geology of the Deep River coal field, North Carolina: U.S. Geol. Survey Prof. Paper 246, 159 p.

Savannah River Laboratory, 1976, Hydrogeological and stream sediment reconnaissance - eastern United States: U.S. Energy Research and Devel. Adm. GJBX-27(76), Open-File Rept., p. 29.

Toenger, A. L., Turnbull, L. A., Shields, J. J., and Haley, W. A., 1952, Investigation of field and estimated reserves of coal, in coal deposits in the Deep River field, Chatham, Lee and Moore Counties, N. C.: U.S. Bur. Mines Bull. 515, pt. 1, p. 1-10. 
Form ERDA 426

(2/i5)

ERDAM 3201
U.S. ENERGY RESEARCH \& DEVELOPMENT ADMINISTRATION

MAJOR CONTRACTOR'S RECOMMENDATION FOR

DISPOSITION OF SCIENTIFIC AND TECHNICAL DOCUMENT

*See Instructions on Reverse

1. ERDA Report No.

GJBX-8 (78)

2. Subject Category No.

3. Title Preliminary Study of the Uranium Potential of the Triassic Sanford Basin and Colon Cross Structure, North Carolina.

4. Type of Document (" $X$ " one)

X a. Scientific and Technical Report

b. Conference paper:

Title of conference

Date of conference

Exact location of conference

c. Other (Specify, Thesis, Translation, etc.)*

5. Copies Transmitted (" $X$ " one or more)

a. Copies being transmitted for standard distribution by ERDA-TIC.

$\square$ b. Copies being transr nitted for special distribution per attached complete address list.*.

Q c. Two completely legible, reproducible copies being transmitted to ERDA-TIC.

6. Recommended Distribution (" $X$ " one)

Q a. Normal handling (after Patent clearance): no restraints nn distilluution except as may be required by the security classification.

$\square$ b. Make available only to U:J. Government agencies and their contractors.

1 c. Make available only within ERDA and to ERDA contractors.

$\square$ d. Make available only within ERDA.

$\square$ e. Make available only to those listed in item 12 below.

f. Other (Specify)*

\%. Recommended Announcement (" $x$ " onie)

a. Normal procedure may be followed.*

$\square$ b. Recommend following announcement limitations:

8. Reason for Restrictions Recommended in 6 or 7 above.

$\square$ a. Preliminary information.

$\square$ b. Prepared primarily for internal use.

$\mathrm{n} / \mathrm{a}$

$\square$ c. Other (Explain)

9. Patent Clearance (" $X$ " one) $n / a$

$\square$ a. ERDA patent clearance has been granted by responsible ERDA patcnt group.

b. Document has been sent to rcspólisible ERDA patent group for clearance.

10. National Security Information (For classified document only; " $X$ " one) $\mathrm{n} / \mathrm{a}$

$\square$ a. Document does contain national security Information other than restricter data.

b. Document does not contain national sersurity irifurmation other than restricted data.

11. Cony Roproduction and Distribution

a. Total number of copies reproduced

$n / a$

b. Number of copies distributed outside originating organization

12. Additional Information or Remarks (Continue on separate sheet, if necessary)

$\mathrm{n} / \mathrm{a}$

13. Submitted by (Name and Position) (Please print or type)*

Sara T. Murphy, Sr._._ibrarian

14. Organization

Bendix Field Engineering Corp. Contractor to U.S. Doe Grand Junction, Como.

15. Signature

16. Date Jan. 24,1978 


\section{INSTRUCTIONS}

Who uses this Form: All ERDA contractors except those specifically instructed by their ERDA contract administrator to use the shorter Form ERDA-427.

When to Use: Submit one copy of this Form with each document which is sent to ERDA's Techncial Information Center (TIC) in accordance with the requirements of ERDA Manual Chapter 3201.

Where to send: Forward this Form and the document(s) to:

$$
\begin{aligned}
& \text { USERDA-TIC } \\
& \text { P.O. Box } 62 \\
& \text { Oak Ridge, TN } 37830
\end{aligned}
$$

\section{Item instructions:}

Item 1. The first clement in the number shall be an ERDAapproved code to be determined as follows: (a) The responsible field office may icquest TIC approval of a unique code for a contractor, e.g., BINL, BMI, HNL, etc.; (b) A program division may request TIC approval of a unlque codo for a program or series of reports, e.g., PNE, VUF, etc.; (c) An operations office may instruct a contractor to use the code approved for the operations office, i.c., COO, ORO, IDO, SRO, SAN, ALO, RLO, NVO; and (d) Program divisions shall use the code ERDA for reports which they themselves prepare unless there is reason to use some other approved code.

The code shall be followed by a sequential number, or by a contract number plus a sequential number, as follows: (a) Contractors or programs with unique codes may complete the report number by adding a sequential number to the code, e.g., HNL-101, HNL-102, etc.; or PNE-1, PNE-2, etc.; or they may add the identifying portion of the contract number and a sequential number, e.g., $A B C-2105-1$, $\mathrm{ABC}-2105-2$, etc; (b) Contractors using the operations uffice code shall complete the report number by adding the identifying portlun of the contract number and a sequential number, e.g., COO-2200-1, COO-2200-2, etc.; (c) Subcontractor reports shall be identified with the code used by the prime contractor; and (d) Program divisions using the ERDA code shall complete the report number by adding a sequential number which they request from the Library Branch, Division of Administrative Services.

Item 2. Insert the appropriate subject category from TID-4500 ("Standard Distribution for Unclassified Scientific and Technical Reports") or M-3679 ("Standard Distribution for Classified Scientific and Technical Reports") for both classificd and unclassified documents, whether or not printed for standard distribution.

Item 3. Give title exactly as on the document itself unless title is classified. In that case, omit title and state "classified title" in the space for item 3.

Item 4. If box $\mathrm{c}$ is checked, indicate type of item being sent, e.g., thesis, translation, etc.

Item 5. a. If box a is checked, the number of copies specified for the appropriate category or categories in M-3679 or TID-4500 shall be forwarded to TIC for distribution.

b. If box $b$ is checked, complete address list must be provided TIC. c. If box c is checked, at least one copy shall be original ribbon or offset and be completely legible. A clear carbon copy is acceptable as a second reproducible copy.

Item 6. If box a is checked for an unclassified document, it may be distributed by TIC (after patent clearance) to addressees listed in TID-4500 for the appropriate subject category, to libraries in the U.S. and abroad, which through purchase of microfiche maintain collections of ERDA reports, and to the National Technical Information Service for sale to the public.

If box a is checked for a classified document, it may be distributed by TIC to addressees listed in M-3679 for the appropriate subject category.

If a box other than a is checked, the recommended limitation will be followed unless $\mathrm{IIC}$ receives other instructions from the responsible ERDA program division.

Box f may be checked in order to specify special instructions, such as "Make available only as specifically approved by the program divislun," etc.

Item 7. a. Announcement procedures are normally determined by the distribution that is to be given a document. If box a in item 6 is checked for an unclassified document, it will normally be listed in the weekly "Accessions of Unlimited Distribution Reports by TIC" (TID-4401) and may be abstracted in "Nuclear Science Abstracts" (NSA).

A classified document, or an unclassified document for which box b, c, d, e, or $f_{1}$. in item 6 is checked, may be cited with appropriate subject index terms in "Abstracts of Limited Distribution Reports" (ALDR).

b. If the normal announcement procedures doseribed in $7 \mathrm{a}$ are not appropriate check $7 \mathrm{~b}$ and indicate recommended announcement limitations.

Item 8. If a box other than a is checked in item 6 , or if $7 \mathrm{~b}$ is cherked, state reason for the recommended restriction, e.g., "preliminary information," "prepared primarily for internal use," etc.

Item 9. It is assumed that there is no objection to publication from the standpoint of the originating organization's patent interest. Otherwise explain in item 12.

Item 10. If box a is checked, document cannot be made availablc to Access Permit holders (Code of Federal Regulations, 10 CFR, Part 25, subpart 2.5.6); if box $\mathrm{b}$ is checked, TIC will determine whether or not to make it available to them.

Item 11. Self explanatory.

Item 12. Use this space if necessary to expand on answers given above, e.g., item $6 \mathrm{f}$ and item 8 .

Item 13. Enter name of person to whom inquiries concerning the recommendations on this Form may be addressed.

Item 14-16. Self explanatory. 


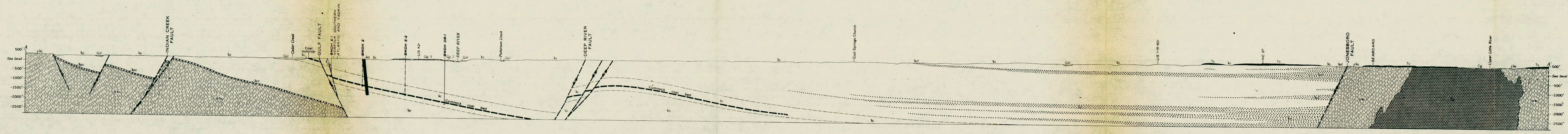

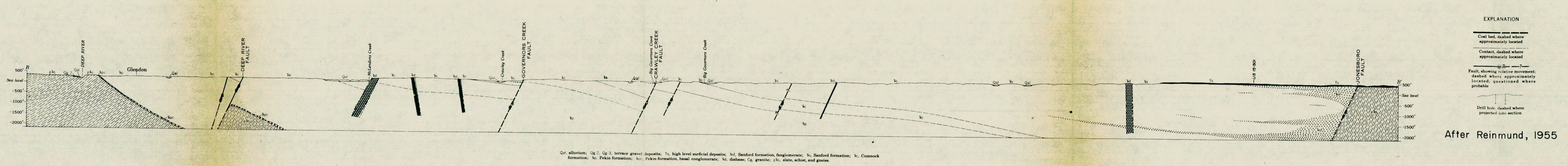

